\title{
Higher Order Thinking Skills (HOTs) based Assessment for Learning: A Model for Computer Networks Learning in Vocational School
}

\author{
Muhammad Yassir $^{1}$, Husain Syam², Hasanah Nur $^{3}$ \\ ${ }^{1}$ Department of Vocational Education, Universitas Negeri Makassar \\ Indonesia \\ Email: yassirnawawi [AT] gmail.com \\ ${ }^{2}$ Department of Engineering, Universitas Negeri Makassar \\ Indonesia \\ Email: husainsyam [AT] unm.ac.id \\ ${ }^{3}$ Department of Engineering, Universitas Negeri Makassar \\ Indonesia \\ Email: hasanahunm [AT] yahoo.com
}

\begin{abstract}
Vocational High School is a kind of school that has a strategic role in fulfilling labors. One of the competencies that graduates of Vocational High School must have is the Higher Order Thinking Skills (HOTS). Many graduates of Vocational High School are not absorbed by industry because they do not have HOTS. This study aims to develop a HOTS-based Assessment for Learning (AFL) model that can be applied to learning computer networks for vocational students. This research is a development research using the modified model of Hopkins and Clark - Analysis, Design, Development, Implementation, and Evaluation (HC-ADDIE), which is a collaboration and modification of research, development, and diffusion model of the Hopkins and Clark - Instructional System Design - Analysis, Design, Development, Implementation, and Evaluation (HC-ISD ADDIE), and Classroom Action Research (CAR). The development stage includes designing a prototype model, validating the model, testing legibility, training teachers / observers, and implementing limited and expanded trials. The results showed that the HOTS-based AFL model of computer network learning for vocational students was successfully developed through the HC-ADDIE modified model.
\end{abstract}

Keywords--- AFL, HOTS, computer network learning, students of vocational high school

\section{INTRODUCTION}

Vocational High School is a formal education that aims to prepare students to enter the world of work, prepare students to master the knowledge, skills, attitudes and values needed by the world of work [1]. Graduates of Vocational High School are required to be able to work independently, have a professional attitude in the field of expertise they are interested in and have competencies in accordance with the chosen expertise program.

The fact is that Vocational High School graduates have not been able to answer employment problems that are needed by the world of work [2]. Moreover, if we look at the data of Statistics Indonesia in 2018, South Sulawesi Province ranks 6th highest in the Vocational High School Open Unemployment Rate, which is $12.48 \%$ even above the national average of $11.24 \%$. For example, the number of alumni, especially the Computer and Network Engineering Department produced by a number of favorite Vocational High School in South Sulawesi, also shows a sad phenomenon, namely those who work according to the background of expertise taken at Vocational High School are no more than 5. \% of the average graduate. Even though, this expertise course is the most preferred department at Vocational High School. We can predict how other schools are doing. Nationally, the computer engineering and informatics department is in the third position of contributors to unemployment for alumni in 2018 , amounting to 228,554 people.

One of the obstacles to the acceptance of Vocational High School graduates in the world of work is the ability to think highly. This is in accordance with the opinion of Delise, Rose and Nichole that the ability to think and work at a high level is one of the competency requirements that must be possessed in the world of work [2]; [3]. The ability to think at a high level is now known as Higher Order Thinking Skills (HOTS). 


\subsection{Higher Order Thinking Skills (HOTS)}

Currently, the learning design at Vocational High School has been directed at HOTS. One of the reasons is the development of the National Exam questions continues to be improved so that it can measure students' abilities in the higher cognitive domains..."[4]. On the other hand, many vocational teachers still use the low-level thinking skills (LOTS) assessment, which only facilitates students in short-term memory [5]. This phenomenon is not only a local problem, but also a global problem. There is international concern about the dominant practice of LOTS assessment which only encourages students to focus on learning that emphasizes rote [6]. As a result, graduates are less skilled and lack high-order thinking skills to solve problems in life [7].

Vocational schools must also be able to prepare their graduates to enter the world of work in accordance with the specified requirements. [8] and [9] stated that to enter the world of work, prospective workers must have the readiness, abilities, and skills required by the labor force (job skills), one of which is HOTS. According to [9], with HOTS a person will be able to learn, provide reasoning, think creatively, make decisions, and solve problems (problem solving).

Some of the abilities mentioned above can be achieved if someone is able to apply knowledge, analyze problems, evaluate problems, and compile alternative problem-solving designs based on their knowledge and understanding. Several indicators of this ability are summarized in HOTS, so HOTS is a must-have for all students, including computer and network engineering students. Therefore, HOTS development is a very important in the educational curriculum for computer and network engineering students.

\subsection{Assessment for Learning}

Currently, the learning design in Vocational High School has been directed at HOTS, so the development of the HOTS assessment is a priority. Assessment is a process carried out as a step to evaluate the performance of the whole system, analyze the effectiveness of teaching, and obtain information in the framework of student decision making which aims to improve the quality of learning [10].

The assessment process in Vocational High Schools must be carried out in all aspects of student abilities so that the assessment results have meaning for students, both for entering the world of work and for continuing education to a higher level. This is in accordance with the Regulation of the Minister of Education and Culture of the Republic of Indonesia Number 66 of 2013 concerning Education Assessment Standards, which states that the scope of assessment of student learning outcomes includes competency attitudes, knowledge and skills which are implemented in a balanced manner so that they are balanced. can be used to determine the position of each student relative to the standards that have been set. It was agreed by [11] that by conducting HOTS assessments regularly, there will be positive developments in students, namely the ability to think and performance will increase as a whole.

Learning Computer and Network Engineering In general, the thinking ability of Vocational High School students is still low. When doing the exercises, students can do their job well based on teacher demonstrations and worksheets. However, when they find an error, they have not been able to analyze the cause of the error (analysis level C4), evaluate the error steps (evaluation level C5) and come up with a solution to manage the error (manufacture level C6). The biggest problem faced by students is the difficulty in generating ideas [7]. This pattern is the same as research which states that the highest learning styles for vocational high school students are actors and the lowest are thinkers [7]. Therefore, it is necessary to think about the HOTS development strategy of computer and network engineering students.

Assessment with these characteristics has advantages, including being able to detect students 'weaknesses and strengths, being able to detect the position of students' abilities in learning based on criteria not compared to other students, involving teachers and students in the implementation process, and being able to help teachers and students achieve the expected learning goals. . In addition, assessment can foster motivation, responsibility, self-confidence, independence, honesty, and student achievement in learning [12]. Yusuf agreed that the function of the assessment is to provide information and control the quality of education which includes all components of education, from the implementation process to educational products [13].

The development of students in Computer and Network Engineering HOTS is a demand that must be done immediately, considering that the characteristics of work in the field of computer and network engineering are to produce or produce products related to the network world that require critical and creative thinking skills. This is because in general the installation and configuration process requires a long problem-solving process, namely: (1) developing a network concept; (2) designing a network which includes making topologies and making network designs; (3) raw material selection; (4) determining the technology used; (5) the installation and configuration process; and (6) testing; Therefore, students as computer and network engineering must be ready and able to master well in accordance with the demands of the global world. Based on the description above, it can be said that an increase in the assessment of student learning outcomes can be done by developing a HOTS-based assessment model. Therefore, this research was conducted to develop a HOTS-based 
Assessment For Learning (AFL): a model for Computer Network learning in Vocational High Schools. The media for Assessment for Learning (AFL) is an application developed based on the management of student learning assessments.

\section{RESEARCH METHOD}

Step 1: Research

The research stages in this research include: (a) problem analysis; and (b) needs analysis based on the results of HOTS preliminary studies, learning motivation, positive attitudes and behavior of students, curriculum (syllabus, lesson plans, learning materials, and assessment systems) as well as theoretical and empirical studies of related theories and theories. research results with HOTS, assessment systems, AFL, vocational education, \& the demands of the global workforce (work ability).

\section{Step 2: Development}

Based on the results of the research stages, the next development stage was carried out. This development stage is carried out to produce a model and a set of HOTS-based AFL model instruments for learning computer and network engineering for students which includes designing a prototype model, model validation activities,

model readability tests, teacher / observer training and model trials both limited and extended trials using the classroom action research (CAR) approach to produce a HOTS-based AFL model that is good, appropriate, and worthy of use.

\section{Step 3: Diffusion}

The diffusion stage is the final stage of this research which includes the dissemination of the development model intended to disseminate the results of this research through socialization in the form of the publication of research results in the form of research seminars, national and international seminars, and journals.

\section{RESULT AND DISCUSSION}

Step 1: Research

Results of the Preliminary Study Review

Vocational School students with HOTS in the field of computer networks which include the ability to apply, analyze, evaluate, and create are generally still low enough that they need to be improved and developed. This is indicated by the low ability of students in applying theory to solve problems, think critically, provide logical reasons and arguments, solve problems, make decisions, and compose concepts and designs / designs in the process of creating new products when students are finished. assignments given by the teacher. Most students also have difficulty writing or compiling scientific papers. This is apparently due to the lack of time to read and not being used to using HOTS skills during the learning process and in the process of completing assignments / questions.

\section{Results of Theoretical and Empirical Studies}

HOTS development, learning motivation, positive attitude and student motivation in the field of computer networks are very important. Therefore, learning strategies and learning models in the field of computer networks in vocational schools must be able to develop HOTS, learning motivation, positive attitudes and student motivation, in order to produce pious, intelligent, and independent learning outcomes and be able to present increasingly complex learning outcomes. global challenges. HOTS development, learning motivation, positive attitudes and student motivation can be done by implementing HOTS-based AFL in the learning process of computer networks in the classroom as an effort to prepare the workforce needed in the 21 st century.

\section{Results of Problem Analysis and Needs Analysis}

The results of the problem analysis show that: (1) Vocational High School students in the field of computer networks still have quite low HOTS, even though students should already have high enough HOTS to be able to face the challenges of an increasingly complex global world. ; (2) students also still have low learning motivation, positive attitudes and behavior, even though this aspect is very important to support student learning success; (3) the learning strategies and assessment systems applied so far have not been able to develop HOTS, learning motivation, positive attitudes and positive student behavior even though they should have been developed either through learning strategies or assessment systems; (4) In the learning process in the field of computer networks, the assessment model has not been integrated, namely the assessment for learning (AFL) for the purpose of HOTS development, learning motivation, student attitudes and positive 
behavior even though they are actually being developed. through the application of AFL in classroom learning; (5) most of the questions / assignments given by the teacher still measure students 'cognitive abilities at a low level (low order thinking skills, LOTS), while at the student level questions / assignments must measure and develop students' cognitive abilities. at a higher level (higher order thinking skills, HOTS); and (6) HOTS-based AFL model for learning computer networks of Vocational High School students does not yet exist, so it is necessary to develop a HOTS-based AFL model for computer learning so that it can be immediately applied in classroom learning as an effort to develop HOTS, learning motivation, positive student attitudes and behavior and improve and improve the quality of learning in the field of computers at Vocational High School.

Step 2: Development

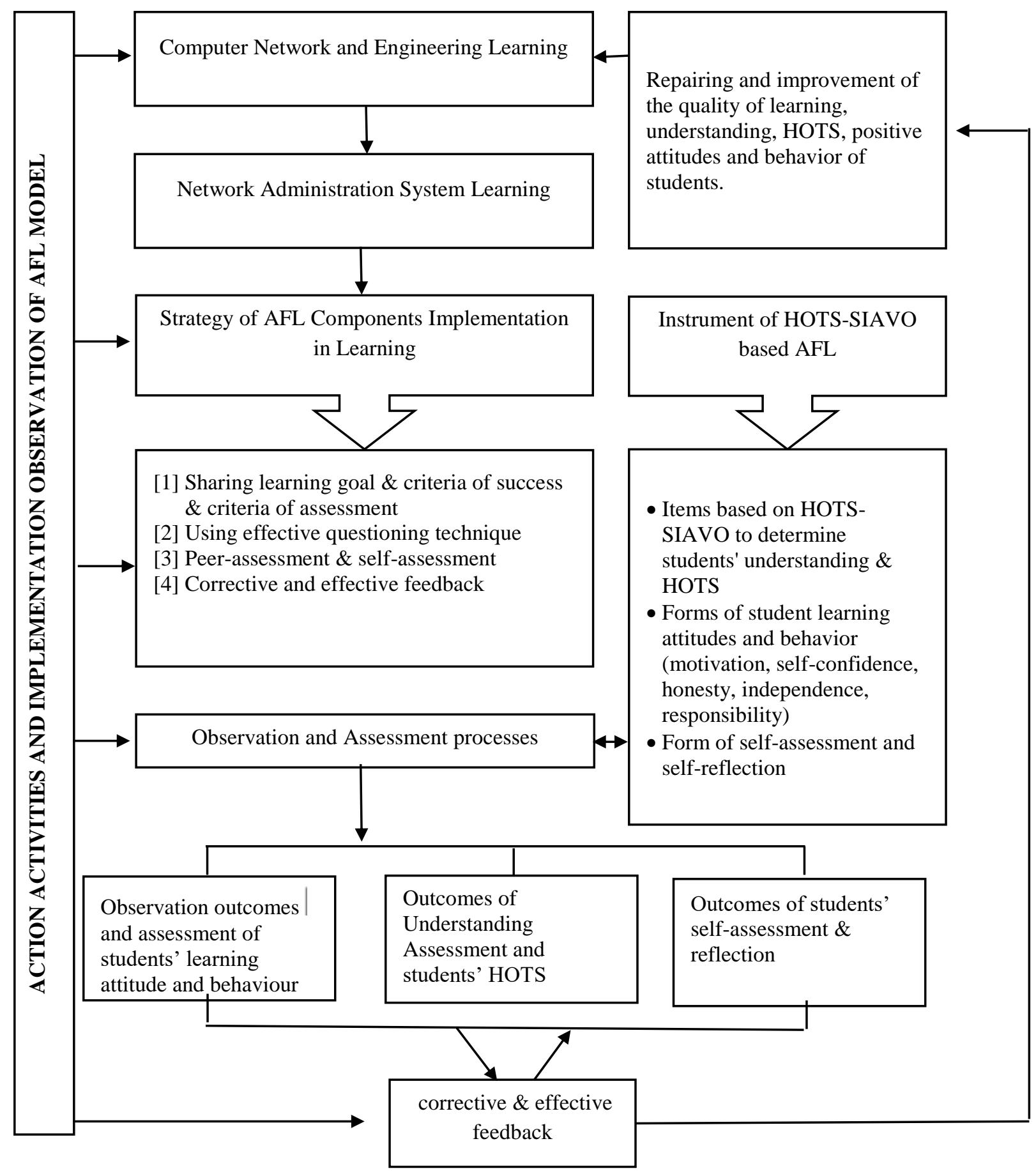

Figure 1. Results of HOTS-Based AFL Model Development 
Table 1. Results of Observation of the Application and Implementation of the HOTS-Based AFL Model

\begin{tabular}{|c|c|c|c|c|c|c|c|c|c|c|c|c|c|c|c|}
\hline \multirow{3}{*}{ Cycles } & \multicolumn{12}{|c|}{ Total Mean and Score (\%) Implemented Model } & \multirow{2}{*}{\multicolumn{2}{|c|}{ Average }} & \multirow{3}{*}{ Desc. } \\
\hline & \multicolumn{6}{|c|}{ Limited Trial } & \multicolumn{6}{|c|}{ Expanded Trial } & & & \\
\hline & \multicolumn{2}{|c|}{ Rater 1} & \multicolumn{2}{|c|}{ Rater 2} & \multicolumn{2}{|c|}{ Rater 3} & \multicolumn{2}{|c|}{ Rater 1} & \multicolumn{2}{|c|}{ Rater 2} & \multicolumn{2}{|c|}{ Rater 3} & Score & $\%$ & \\
\hline 1 & 22 & 79 & 24 & 86 & 24 & 86 & 26 & 93 & 26 & 93 & 26 & 93 & 24.7 & 88.3 & Good \\
\hline 2 & 24 & 86 & 25 & 89 & 25 & 89 & 26 & 93 & 26 & 93 & 26 & 93 & 25.3 & 90.5 & Good \\
\hline 3 & 28 & 100 & 28 & 100 & 28 & 100 & 28 & 100 & 28 & 100 & 28 & 100 & 28 & 100 & Good \\
\hline Average & 24.7 & 88.3 & 26 & 92 & 26 & 92 & 27 & 95.3 & 27 & 95.3 & 27 & 95.3 & 26 & 92 & Good \\
\hline
\end{tabular}

\section{CONCLUSION}

The procedure for developing the HOTS-based AFL model in this study uses the HC-ADDIE modification model development procedure, namely the collaboration and modification of the Hopkins \& Clark RDD model and the ISDADDIE model, which includes three stages, namely the research, development, and diffusion stages. The research phase includes analysis of preliminary studies, analysis of theoretical and empirical studies (research results related to HOTS, AFL, and vocational education), problem analysis, \& needs assessment. The development stage includes the design of the prototype model, validation, and testing with the classroom action research approach to implement $\&$ evaluate both on limited and extended trials, so that the model and model instruments are declared valid, reliable, and fit for use both theoretically and empirically. The diffusion stage includes dissemination of results through results seminars and journal publications.

The characteristics of the HOTS-based AFL model developed in this study include:

1. The assessment process is integrated in the learning process and is ongoing so that the weaknesses and strengths of students can be detected properly.

2. The assessment process applies the concepts, principles, strategies and four elements (components) of AFL, namely: explaining the learning objectives, success criteria, and assessment criteria (sharing learning goals, criteria of success, and criteria of assessment), using effective questions (using effective) questioning), involving students in assessment through self-assessment and self-reflection (self-assessment \& self-reflection), and providing positive and effective feedback (corrective \& effective feedback).

3. The assessment process aims to improve and develop students' understanding and HOTS, so that the assessment process focuses on developing the ability to understand, apply, analyze, evaluate, and create. Therefore, the questions / assignments given emphasize increasing the understanding and development of students' HOTS (HOTS-based).

4. The assessment process is able to bring up information-about understanding, HOTS, as well as student attitudes and behavior in the learning process.

5. The teacher can provide HOTS-based questions / assignments, in the form of problems to students as material for discussion and problem solving to stimulate student thinking activities

6. The assessment activities can be applied to theoretical learning (by applying problem-based learning) and practical learning (by applying project-based learning)

7. The procedure for developing a HOTS-based question / task device that is able to provide information about the level of understanding and HOTS of students in the HOTS-based AFL model is through several stages, namely:

a. The stage of identifying the developed competencies and formulating indicators

b. The stage of constructing HOTS-based questions / tasks

c. Expert validation stage

d. The empirical test stage

8. The procedure for applying the HOTS-based AFL model in the field of computer network engineering at Vocational High School is manifested in a syntax which includes three stages, namely: (a) the preparation stage; (b) the implementation stage of sharing learning goals and criteria of assessment, using effective questioning technique, selfassessment \& self-reflection, feedback; and (c) the reporting stage of the assessment results, accompanied by a model implementation guide.

9. The information that can be raised from the application of the HOTS-based AFL model in the field of computer network engineering at Vocational High School is the conditions of understanding, HOTS, positive attitudes and behavior of students. 
10. How to collect information to assess students 'position of understanding and HOTS in learning using the HOTS-based AFL model is through a set of assessment instruments for students' understanding and HOTS which include: (a) HOTSbased question sheets / assignments equipped with an assessment rubric and scoring guidelines; (b) the student's understanding and HOTS assessment sheet; (c) student activity observation sheets; and (d) student self-assessment and self-reflection sheets (self-assessment \& self-reflection).

11. How to analyze and interpret the information on the assessment results data is carried out quantitatively and qualitatively according to the objectives and types of information obtained and then communicated on predetermined assessment criteria so that the level of student learning achievement can be known.

12. How to report the results of the assessment in the HOTS-based AFL model is through student profiles both individual student profiles and class profiles that are packaged comprehensively using quantitative and qualitative data based on:

a. The results of the assessment of student understanding are seen from the performance of students in solving HOTS-based questions / assignments

b. The results of the assessment of student understanding based on self-assessment \& self-reflection

c. Student HOTS assessment results

d. The results of the assessment of students' positive attitudes and behaviors for each subject and for the entire subject

13. Information on the results of this assessment includes: the total performance score obtained, the maximum total score that should be achieved, the percentage (9\%) of the material mastery that has been achieved, the results of the selfassessment \& self-reflection assessment, the HOTS assessment results (ability to apply-apply, analyzing-analyzing, evaluating-evaluating, and creating-creating, the results of the assessment of student attitudes \& behavior (learning motivation, honesty, self-confidence, independence, and responsibility), the maximum criteria that should be achieved, and feedback (feedback) from the teacher .

14. How to use the information on the results of the assessment in the HOTS-based AFL model can be done in three stages, namely: (1) reviewing the results of the assessment; (2) reflect on the strengths and weaknesses they have; and (3) receive or provide feedback (feedback) for both students and teachers which aims to improve and improve the quality of results.

15. The results of testing the effectiveness of the HOTS-based AFL model in improving vocational students 'understanding and HOTS have shown that the HOTS-based AFL model was able to significantly increase students' understanding and HOTS during learning. Thus it can be said that the HOTS-based AFL model is proven to be effective in increasing the understanding and HOTS of vocational students. Therefore, the HOTS-based AFL model is feasible to be applied in learning the field of computer network engineering at Vocational High School.

\section{REFERENCES}

1. Jabidi A, Slamet A, Khumaedi M. Kompetensi Kewirausahaan Siswa Sekolah Menengah Kejuruan. Journal of Vocational and Career Education [Internet]. 2017 Dec 11 [cited 2021 Feb 19];2(2). Available from: https://journal.unnes.ac.id/nju/index.php/jvce/article/view/13812

2. Alimudin IA, Permana T, Sriyono S. STUDI KESIAPAN KERJA PESERTA DIDIK SMK UNTUK BEKERJA DI INDUSTRI PERBAIKAN BODI OTOMOTIF. Journal of Mechanical Engineering Education. 2018;5(2):1917 .

3. Rose C, Nicholl MJ. Accelerated learning for the 21st century : cara belajar cepat abad XXI. Bandung: Nuansa; 2002.

4. Akuntono I. 2013, Pendidikan Nasional Sarat dengan Masalah Krusial [Internet]. KOMPASIANA. 2014 [cited $2021 \mathrm{Feb} 19]$. Available from: https://edukasi.kompas.com/read/2014/01/02/1508506/2013.Pendidikan.Nasional.Sarat.dengan.Masalah.Krusial

5. Nugroho RA. HOTS (Kemampuan Berpikir Tingkat Tinggi: konsep, pembelajaran, penilaian, dan soalsoal). Jakarta: Gramedia Widiasarana Indonesia; 2018.

6. Osborne J, Dillon J. Science Education in Europe: Critical Reflections. In: A Report to the Nuffield Foundation. London; 2008.

7. Heong YM, Othman WB, Yunos JBM, Kiong TT, Hassan RB, Mohamad MMB. The Level of Marzano Higher Order Thinking Skillsamong Technical Education Students. IJSSH. 2011;1(2):121-5.

8. Cotton K. Developing Employability Skills. USA; 1993.

9. Robinson JP. Information_Grade10_WhatAreEmployabilitySkills.pdf. ALABAMA COOPERATIVE EXTENSION SYSTEM [Internet]. 2000 Sep 15 [cited 2021 Feb 19];1(3). Available from: 
https://www.middletowncityschools.com/media/studentservices/Information_Grade10_WhatAreEmployabilitySkil 1s.pdf

10. Abosalem Y. Assessment Techniques and Students' Higher-Order Thinking Skills. International Journal of Secondary Education. 2016 Mar 7;4(1):1.

11. Brookhart SM, Nitko AJ. Assessment and grading in classrooms. New Jersey: Pearson Mermill Prentice Hall; 2008.

12. Chappuis S, Stiggins RJ. Classroom Assessment for Learning. Educational Leadership. 2002 Sep;60(1):5.

13. Miarso Y. Menyemai benih teknologi pendidikan. Jakarta: Kencana; 2007. 